\title{
Comment on 2019 ESC Guidelines for the management of patients with supraventricular tachycardia
}

\author{
Komentár k Odporúčaniam ESC pre manažment pacientov \\ so supraventrikulárnymi tachykardiami z roku 2019
}

\author{
Hlivák P, Hatala R
}

Národný ústav srdcových a cievnych chorôb, a. s. a Lekárska fakulta Slovenskej zdravotníckej univerzity v Bratislave, Slovenská republika
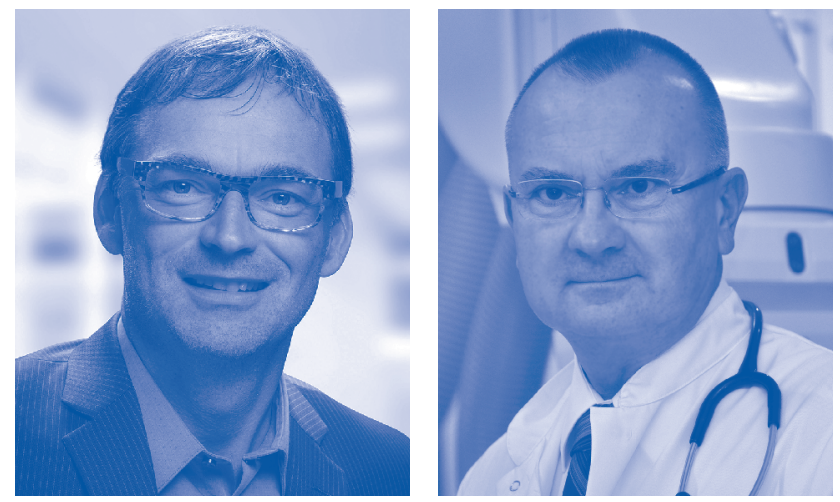

Odporúčania ESC pre manažment pacientov so supraventrikulárnymi tachykardiami (SVT) 2019 (d’alej len odporúčania) boli v plnej verzii prezentované počas výročného kongresu ESC v Paríži a paralelne publikované 31. augusta 2019 (1). Dokument ESC je napísaný na 65 stranách vrátane 598 citácií, o ktoré sa jednotlivé triedy odporúčaní opierajú, pričom v tabul'kách je väčšina odporúčaní podložená úrovňou dôkazov B (80) a C (64) a len tri dosahujú úroveň dôkazov A. Nová aktualizácia predstavuje zásadne prepracovaný dokument prichádzajúci po 16 rokoch - pôvodné spoločné odporúčania európskych a amerických odborných spoločností sú z roku 2003 (2).

Dokument obsahuje odporúčania pre manažment prakticky všetkých SVT okrem fibrilácie predsiení,

Z Národného ústavu srdcových a cievnych chorôb, a. s. a Lekárskej fakulty Slovenskej zdravotníckej univerzity v Bratislave, Slovenská republika Do redakcie došlo dňa 28. februára 2021; prijaté dňa 3. marca 2021 ktorú per se k supraventrikulárnym tachykardiám nezaradujeme a jej manažmentu sa venujú samostatné odporúčania (3). Pojmom supraventrikulárna tachykardia sa doslova označuje tachykardia (frekvencia predsiení $>$ 100/minútu v pokoji), ktorej mechanizmus zahŕňa štruktúry srdca z oblasti Hisovho zväzku alebo nad ním. $\mathrm{V}$ tradičnom ponímaní sa pojmom SVT označovali všetky typy tachykardií okrem komorových tachykardií (KT) a fibrilácie predsiení, a teda zahŕňal aj tachykardie ako atrioventrikulárne (AV) reentry tachykardie na podklade existencie akcesórnej dráhy, pri ktorej v podstate nejde o supraventrikulárny rytmus. Základná EKG klasifikácia rozdeluje tachykardie podla dĺžky trvania komplexu QRS na dve kategórie:

- Pojmom tachykardia s úzkym komplexom QRS (tzv. úzkokomplexové) sa označujú tachykardie, pri ktorých je trvanie komplexu QRS $\leq 120$ milisekúnd (ms).

- Tachykardia so širokým komplexom QRS (tzv. širokokomplexová) je tachykardia s trvaním komplexu QRS > 120 ms.

Diferenciálna diagnostika SVT sa v tomto zmysle člení na tri základné kategórie:

1. tachykardie s úzkym komplexom QRS

2. tachykardie so širokým komplexom QRS

3. iregulárne tachykardie

Neotrasitelnú pozíciu v diferenciálnej diagnostike si udržuje 12-zvodový EKG záznam získaný počas

Adresa pre korešpondenciu: MUDr. Peter Hlivák, PhD., NÚSCH, a. s., Pod Krásnou hôrkou 1,833 48 Bratislava, Slovenská republika, e-mail: hlivakp@ gmail.com 
tachykardie. Klinický význam záznamov z biosenzorov schopných snímat jednozvodový EKG záznam doposial nebol adekvátne validovaný. Dokument sa pomerne detailne venuje elektrokardiografickej diferenciálnej diagnostike tachykardií, táto má však významné obmedzenia pre správnu a rýchlu diferenciáciu komorových tachykardií (KT). Akýkolvek algoritmus diferenciácie SVT od KT je limitovaný nízkou špecificitou diagnostiky KT (40 - 80 \%) a nízkou diagnostickou presnostou (75 \%). To je ale, žial', presnost' porovnatel'ná s jednoduchým empirickým odporúčaním považovat každú tachykardiu so širokým komplexom QRS za komorovú.

\section{Klúčové rozdiely $\mathrm{v}$ aktuálnych odporúčaniach sa v porovnaní s ostatnou verziou pre manažment SVT z roku 2003 týkajú nasledovných oblastí:}

\section{Katétrová ablácia}

Triedy odporúčaní a úrovne dôkazov pre katétrovú liečbu v dlhodobom manažmente SVT dosiahli vo všeobecnosti vyšší stupeň pre takmer všetky typy SVT. Sú odrazom nakumulovaných skúseností za posledné roky celosvetovo a paralelne publikovaných výsledkov týkajúcich sa vysokej efektivity a relatívne nízkeho rizika komplikácií uvedenej liečebnej modality. Vo väčšine prípadov SVT dosiahla katétrová ablácia Triedu odporúčaní I, s úrovňami dôkazov $\mathrm{B}$ alebo dokonca A. Súčasná technológia katétrovej ablácie s použitím elektroanatomického mapovania dovoluje v skúsených centrách eliminovat aj akcesórne dráhy $\mathrm{v}$ parahisárnych lokalizáciách s velmi nízkym rizikom iatrogénnej AV blokády. Rovnako možno bezpečne a vysoko efektívne využit katétrovú abláciu pre kauzálnu liečbu SVT $\mathrm{v}$ gravidite bez použitia RTG žiarenia.

Existujú však aj výnimky, kde je v chronickom manažmente katétrová ablácia indikovaná $\mathrm{v}$ Triede II (môže sa alebo mala by sa zvážit podla konkrétneho typu arytmie): multifokálna atriálna tachykardia, neadekvátna sínusová tachykardia, SVT u pacientov s vrodenými chybami srdca.

\section{Farmakologická liečba}

Triedy odporúčaní a úrovne dôkazov pre medikamentóznu liečbu v dlhodobom manažmente SVT sa vo všeobecnosti oslabili pre takmer všetky typy SVT. Ide o prirodzený dôsledok vyššie spomínanej akumulácie dôkazov účinnosti a bezpečnosti katétrovej ablácie, no zároveň chýbanie spolahlivých dát $\mathrm{z}$ velkých randomizovaných klinických štúdií pre antiarytmickú liečbu v terapii SVT. V odporúčaniach sa prakticky nenachádza žiadne odporúčanie v Triede I pre chronickú antiarytmickú liečbu SVT, okrem betablokátorov pri tachykardiou mediovanej kardiomypatii, aj to až v prípade, kedy katétrová ablácia nebola úspešná alebo ju nebolo možné realizovat'. Úplne z odporúčaní vypadol napríklad sotalol z liečby prvej línie. $\mathrm{V}$ prípade aj u nás pomerne často používaného amiodarónu, ten je indikovaný $\mathrm{v}$ Triede IIb (teda ho možno zvážit', alebo možno o ňom uvažovat') $\mathrm{v}$ chronickom manažmente predsieňových makroreentry tachykardií a u pacientov s SVT v kontexte vrodenej chyby srdca, ked’ nie je možné realizovat katétrovú abláciu alebo táto bola neúspešná. Podobne má amiodarón za sebou slabšiu medicínu dôkazov aj v akútnom manažmente SVT, a to na úrovni Triedy odporúčaní IIb v manažmente širokokomplexových tachykardií, fokálnej predsieňovej tachykardie, predsieňových makroreentry tachykardií a antidrómnej AV reentry tachykardie. Za zmienku stojí, že amiodarón sa už v súčasnosti neodporúča v akútnom manažmente preexcitovanej fibrilácie predsiení vzhladom na dokumentované nežiaduce príhody. Dnes sa jeho miesto $\mathrm{v}$ odporúčaniach $\mathrm{v}$ tejto indikácii dostalo do Triedy III - teda de facto je jeho podanie v tejto indikácii kontraindikované.

Nefarmakologická liečba (okrem katétrovej ablácie)

- Vágové manévre. V akútnom manažmente SVT sa pri hemodynamicky stabilných pacientoch jednoznačne v prvej línii odporúčajú vágové manévre (napríklad Valsalvov manéver alebo masáž karotického sínusu). V prípade Valsalvovho manévra sa v súčasnosti preferuje efektívnejšia modifikácia $\mathrm{u}$ pacienta $\mathrm{v}$ ležiacej polohe s eleváciou dolných končatín.

- Elektrická kardioverzia. Osvedčený a vysoko efektívny terapeutický prístup, ktorý by mal byt realizovaný u pacientov s akoukolvek SVT, ktorá je sprevádzaná hemodynamickou nestabilitou (Trieda I), alebo u pacientov, kde predchádzajúce nemedikamentózne postupy (napríklad vágové manévre) alebo medikamentózna liečba neboli účinné.

Celý dokument je koncipovaný velmi prakticky, no uspokojí aj čitatelov s hlbším záujmom o elektrofyziologické mechanizmy a anatomický substrát, ktoré stoja v pozadí jednotlivých typov SVT (podrobnejšie uvedené vo forme doplnkového materiálu) (4). V úvodnom zhodnotení pacienta s SVT sa zdôrazňuje význam dôkladnej a správne odobratej anamnézy a klúčový prínos elektrokardiografického (EKG) záznamu, osobitne 12-zvodového. EKG tvorí základný pilier diferenciálnej diagnostiky tachykardií s úzkym aj širokým komplexom QRS, ktorá je v aktuálnych odporúčaniach zobrazená schematicky. Velmi jednoduchým dichotomickým spôsobom sa odporúča akútny manažment pre úzko aj širokokomplexové tachykardie, ktorý je determinovaný 
hemodynamickou stabilitou, respektíve nestabilitou (pozri vyššie), a to aj v prípade, že nie je definitívne stanovený pôvod tachykardie. Uvedené sú aj jednotlivé možné odpovede na podanie adenozínu, ktoré nám môžu pomôct v diferenciálnej diagnostike SVT. Oproti predchádzajúcim odporúčaniam sa aj napriek absencii solídnych klinických štúdií posilnila pozícia intravenóznych betablokátorov ako alternatíva $\mathrm{k}$ adenozínu $\mathrm{v}$ akútnom manažmente úzkokomplexových tachykardií (Trieda IIa, úroveň dôkazov C), naopak sa v tejto indikácii oslabilo odporúčanie pre použitie non-dihydropyridínových kalciových blokátorov (verapamil a dilatiazem) z Triedy I na IIa.

V dalšej časti sa autori venujú špecifickým typom SVT, osobitne akútnemu aj chronickému manažmentu. Z celého širokého spektra SVT, ktoré sú podrobne uvedené v odporúčaniach, sa obmedzíme len na komentár $\mathrm{k}$ manažmentu neadekvátnej sínusovej tachykardie, AV nodálnej reentry tachykardie a asymptomatickej preexcitácie.

Neadekvátna sínusová tachykardia prináša nielen zhoršenie kvality života pacientov ( $\mathrm{v}$ drvivej väčšine ide o mladé ženy, často zdravotníčky), ale aj „vrásky na čele“ pre ošetrujúcich lekárov. Odporúčania pre liečbu tejto arytmie kladú dôraz na životosprávové opatrenia, farmakoterapeutické nóvum predstavuje zváženie pridania ivabradínu sólo alebo pri dlhodobej liečbe optimálne v kombinácii s betablokátormi (Trieda IIa). Neadekvátna sínusová tachykardia nepredstavuje vo väčšine prípadov indikáciu pre invazívne elektrofyziologické vyšetrenie. Neuspokojivé výsledky katétrovej ablácie uvedenej arytmie s dlhodobou úspešnostou $<10 \%$ spôsobili, že sa ablácia viac v tejto indikácií neodporúča. Toto zdržanlivé, neintervenčné stanovisko podporujú aj pozorovania, že neadekvátna sínusová tachykardia nebýva príčinou tachykardiomyopatie.

Pri diferenciálnej diagnostike sínusovej tachykardie sa v klinickej praxi nezriedka zabúda na syndróm posturálnej ortostatickej tachykardie. Ide o klinický syndróm charakterizovaný vzostupom srdcovej frekvencie o > 30 úderov/min po zaujatí vzpriamenej polohy, no bez sprievodného poklesu systolického TK o $>20 \mathrm{mmHg}$. Symptómy pri tomto syndróme vel'mi dobre reagujú na rehabilitačný cvičebný program.

AV nodálna reentry tachykardia (AVNRT) je jednou z najčastejších paroxyzmálnych úzkokomplexových tachykardií. $\mathrm{V}$ akútnom manažmente by sa malo začat vágovými manévrami, $\mathrm{v}$ prípade ich neúspechu pokračovat v podaní adenozínu intravenózne vo forme rýchlej bolusovej dávky (6 - $18 \mathrm{mg})$ a ked' ani tento postup nie je účinný, mali by sa zvážit intravenózne nondihydropyridínové kalciové blokátory alebo betablokátory. Ak sú uvedené postupy neefektívne alebo je prítomná hemodynamická instabilita, jednoznačne je indikovaná elektrická kardioverzia. V chronickom manažmente symptomatickej recidivujúcej AVNRT sa vzhladom na vysokú úspešnost' (približne $97 \%$ ) a nízke riziko komplikácií (najmä kompletnej AV blokády, ktoré je $<1 \%$ ) odporúča katétrová ablácia. Z tohto pohladu je postavenie dlhodobej antiarytmickej liečby symptomatickej AVNRT limitované. Z odporúčaní „vypadla“ možnost' stratégie "pill in the pocket", teda tabletky vo vrecku pri paroxyzme a u pacientov s velmi zriedkavými a krátkymi epizódami tachykardie, osobitne ak sú málo symptomatické, sa môže zvážit aj konzervatívny postup so sledovaním, bez akejkolvek liečby.

\section{Manažment pacientov s asymptomatickou} preexcitáciou bol dlhodobo témou rôznych kontroverzií. Za posledné roky pribudlo $\mathrm{v}$ svetovom písomníctve množstvo údajov, ktoré nám pomohli zorientovat sa $\mathrm{v}$ tejto problematike. Väčšina pacientov s elektrokardiografickým obrazom preexcitácie prežije svoj život bez výskytu príhod súvisiacich s ich komorovou preexcitáciou. Približne u jedného z piatich sa však $\mathrm{v}$ živote objavia arytmie súvisiace s prítomnostou akcesórnej dráhy, pričom najčastejšie ide o $\mathrm{AV}$ reentry tachykardiu (80 \%) a u 20 - $30 \%$ môže vzniknút fibrilácia predsiení. Najobávanejšou komplikáciou pacientov s WPW syndrómom je náhla srdcová smrt (NSS) v dôsledku fibrilácie komôr (FK). Riziko zastavenia srdca alebo FK sa odhaduje na 2,4 na 1000 osobo-rokov. Výsledky viacerých štúdií za posledných 30 rokov, ktoré zahón àli aj pacientov s asymptomatickou preexcitáciou, boli inkorporované aj v týchto odporúčaniach. Podobne ako je to $\mathrm{v}$ manažmente aj iných kardiovaskulárnych ochorení, aj tu je dôležitá tzv. riziková stratifikácia, ktorá sa môže realizovat neinvazívne, alebo invazívne. Osobitne u pacientov s rizikovým povolaním (piloti, profesionálni šoféri a podobne) alebo vrcholoví športovci sa s cielom posúdenia rizikových vlastností akcesórnej dráhy, ktorá je podkladom obrazu preexcitácie na EKG, odporúča realizovat invazívne elektrofyziologické vyšetrenie aj s podaním izoprenalínu.

Za vysokorizikovú sa považuje akcesórna dráha vtedy, ked’ má také elektrofyziologické vlastnosti, pri ktorých hrozí v prípade vzniku fibrilácie predsiení prevádzanie elektrických vzruchov z predsiení na komory s velmi vysokou frekvenciou s potenciálom degenerácie do fibrilácie komôr a náhlej srdcovej smrti. $\mathrm{K}$ takým vlastnostiam patria: najkratší preexcitovaný RR interval počas fibrilácie predsiení (SPERRI, $\mathrm{z}$ angl. 
the shortest preexcited RR interval) $\leq 250 \mathrm{~ms}$ alebo efektívna refraktérna perióda (ERP) akcesórnej dráhy $\leq 250$ ms. Neinvazívna riziková stratifikácia nemá takú silu dôkazov ako invazívna (Trieda IIb vs. IIa), k znakom nízkeho rizika patrí náhla a kompletná normalizácia PR intervalu so stratou delta vlny (preexcitácie) pri zátažovom vyšetrení, osobitne ak k takejto zmene dôjde pri nižších srdcových frekvenciách. Problémom rizikovej stratifikácie je rôzna katecholamínová senzitivita v danom čase vyšetrenia $\mathrm{v}$ porovnaní so situáciami v bežnom živote, kedy môže dôjst' $\mathrm{k}$ vzniku preexcitovanej fibrilácie predsiení. V minulosti sa za marker nízkeho rizika považovala aj intermitentná preexcitácia (napríklad počas 24-hodinového monitorovania EKG), no práce $z$ ostatných rokov naznačujú, že viac ako $1 / 5$ pacientov môže mat' ERP akcesórnej dráhy $\leq 250 \mathrm{~ms}$. Preto sa $\mathrm{v}$ súčasnosti považuje tento ukazovatel' za nedostatočný. Pacienti, u ktorých sa potvrdia rizikové vlastnosti akcesórnej dráhy, sú indikovaní na katétrovú abláciu.

Katétrová ablácia akcesórnej dráhy je kuratívnym výkonom, ktorý sa spája v rukách skúseného elektrofyziológa s vysokou úspešnostou (> $95 \%$ ) a nízkym rizikom komplikácií (<0,5\%). Novú indikáciu predstavuje katétrová ablácia aj u pacientov so zníženou funkciou lavej komory a asymptomatickou preexcitáciou, ktorá môže byt' dôsledkom elektrickej dyssynchrónie. $\mathrm{U}$ pacientov s asymptomatickou preexcitáciou, u ktorých sa počas elektrofyziologického vyšetrenia zistí prítomnost̉ nízkorizikovej akcesórnej dráhy, možno uvažovat' (Trieda IIb) o katétrovej ablácii v dostatočne skúsenom centre po dôkladnom poučení pacienta a jeho preferenciách. U pacientov s asymptomatickou trvalou preexcitáciou treba mat’ na pamäti aj skutočnost', že od 5. dekády života sa vo všeobecnosti podstatne zvyšuje riziko vzniku fibrilácie predsiení, čo môže zásadne zmenit’ pohlad na rizikovost’ pôvodne „benígnej“ akcesórnej dráhy.

Hoci sa sa predkladané odporúčania cielene nevenujú problematike fibrilácie predsiení, túto nie je úplne možné obíst' pri zmienke o manažmente flutteru predsiení. Osobitne v otázkach antitrombotickej profylaxie. Ak má pacient súčasne flutter aj fibriláciu predsiení, antikoagulačný režim sa má riadit podla súčasne platných odporúčaní pre manažment pacientov s fibriláciou predsiení (aktuálne z roku 2020) (3). Iná je situácia u pacientov s flutterom predsiení, u ktorých nebola dokumentovaná fibrilácia predsiení. U týchto pacientov nám chýbajú spolahlivé údaje $\mathrm{z}$ velkých randomizovaných štúdií, nebol validovaný prínos skórovacieho systému $\mathrm{CHA}_{2} \mathrm{DS}_{2}$-VASc. Prah na začatie antikoagulácie nebol tak dôkladne študovaný a teda aj stanovený, no zdá sa, že je vyšší v porovnaní s pacientmi s FP (antikoagulácia by sa mala zvážit’ v Triede IIa, úroveň dôkazov C). Jedna $\mathrm{z}$ nedávnych prác naznačuje hranicu na začatie antikoagulácie na úrovni rizika tromboembolizmu $\mathrm{CHA}_{2} \mathrm{DS}_{2}$-VASc $\geq 4$ (5).

Nové odporúčania prinášajú aj návody na manažment SVT v špecifických populáciách, napríklad u dospelých s vrodenými chybami srdca, v pediatrickej populácii, gravidite a pri tachykardiou indukovanej kardiomyopatii. Súhrnne možno konštatovat, že dokument prináša mnohé praktické návody na manažment supraventrikulárnych tachykardií pri širokom spektre pacientov. Akútny manažment má viacero spoločných prvkov pre rôzne typy SVT, v chronickom manažmente sa javí zretelný posun smerom ku katétrovej ablácii arytmogénnych substrátov s marginalizáciou antiarytmickej farmakoterapie.

Základné odkazy nových odporúčaní vo forme „čo robit" $\mathrm{a}$ „čomu sa vyhnút ${ }^{\text {““ }} \mathrm{v}$ manažmente SVT

\section{Čo robit' v manažmente SVT}

1. Vždy ked' to situácia dovolí, je potrebné zaznamenat' 12-zvodový elektrokardiogram.

2. SVT sa môžu prejavovat' ako úzkokomplexové alebo širokokomplexové tachykardie (QRS > $120 \mathrm{~ms}$ ).

3. U pacientov s SVT by sa $\mathrm{v}$ akútnom manažmente malo začat’ s vágovými manévrami, preferenčne $\mathrm{v}$ l'ahu a s eleváciou dolných končatín a podaním adenozínu.

4. U pacientov s SVT, ktorí sú hemodynamicky nestabilní, je indikovaná elektrická kardioverzia. Tá je indikovaná aj u pacientov, u ktorých zlyhajú predchádzajúce nefarmakologické postupy (napríklad vágové manévre) alebo medikamentózna liečba.

5. V chronickom manažmente je pre väčšinu symptomatických rekurentných SVT indikovaná a preferovaná katétrová ablácia. Výnimku tvoria pacienti s multifokálnou atriálnou tachykardiou, neadekvátnou sínusovou tachykardiou, SVT u pacientov s vrodenými chybami srdca a tehotné pacientky v prvom trimestri.

6. Antikoagulačný manažment pacientov s flutterom predsiení bez súčasnej fibrilácie predsiení by sa mal riadit podla odporúčaní pre FP, hoci prah pre začatie nie je tak dobre dokumentovaný ako pri FP.

7. U pacientov so symptomatickým WPW syndrómom je indikovaná katétrová ablácia.

8. U pacientov s asymptomatickou preexcitáciou na EKG by sa mala zvážit riziková stratifikácia invazívne (Trieda IIa) alebo neinvazívne (Trieda IIb). U rizikových povolaní a vrcholových športovcov je indikovaná invazívna stratifikácia počas invazívneho elektrofyziologického vyšetrenia aj s podaním izoprenalínu. 
9. Pri potvrdení rizikových charakteristík akcesórnej dráhy je indikovaná katétrová ablácia.

10. Katétrová ablácia je indikovaná u pacientov s tachykardiou mediovanej kardiomyopatii, ale aj pri asymptomatickej preexcitácii so systolickou dysfunkciou LK pri elektrickej dyssynchrónii.

11. V prípade, že je to možné, treba sa vyhnút všetkým antiarytmikám u tehotných pacientiek v 1 . trimestri.

\section{Čomu sa vyhnút' v manažmente SVT}

1. V akútnom manažmente širokokomplexovej tachykardie, ak nie je jednoznačne určený pôvod, nepodávat’ verapamil.

2. V akútnom manažmente predsieňových makroreentry tachykardií nepodávat propafenón ani flekainid.

3. U pacientov s preexcitovanou fibriláciou by sa nemali podávat' betablokátory, verapamil, diltiazem, digoxín a ani amiodarón, môžu dokonca poškodit'.

4. U pacientov s vrodenými chybami srdca by sa nemal podávat sotalol ako prvolíniové antiarytmikum, vzhladom na vyššie riziko proarytmického účinku a mortality.

5. U pacientov s vrodenými chybami srdca, dysfunkciou komôr a závažným stupňom fibrózy by sa v prvej línii antiarytmickej liečby nemali podávat propafenón ani flekainid.

6. U tehotných žien sa neodporúča amiodarón.

\section{Literatúra}

1. Brugada J, Katritsis DG, Arbelo E, et al. 2019 ESC Guidelines for the management of patients with supraventricular tachycardia. The Task Force for the management of patients with supraventricular tachycardia of the European Society of Cardiology (ESC): Developed in collaboration with the Association for European Paediatric and Congenital Cardiology (AEPC). Eur Heart J. 2020;41:655-720. doi:10.1093/eurheartj/ehz467.

2. Blomstrom-Lundqvist C, Scheinman MM, Aliot EM, et al. Committee, Task Force, and Members ESC. ACC/AHA/ESC Guidelines for the Management of Patients With Supraventricular Arrhythmias-Executive Summary: A Report of the AmericanCollege of Cardiology/American Heart Association Task Force on Practice Guide-lines and the European Society of Cardiology Committee for Practice Guidelines (Writing Committee to Develop Guidelines for the Management of Patients With Supraventricular Arrhythmias). Circulation. 2003;108:1871-1909.

3. Hindricks G, Potpara T, Dagres N, et al.; ESC Scientific Document Group. 2020 ESC Guidelines for the diagnosis and management of atrial fibrillation developed in collaboration with the European Association for Cardio-Thoracic Surgery (EACTS). Eur Heart J. 2021;42:373-498. doi: 10.1093/eurheartj/ehaa612.

4. https://academic.oup.com/eurheartj/article-lookup/doi/10.1093/ eurheartj/ehz467\#supplementary-data (dostupné 24.2.2021)

5. Chen YL, Lin YS, Wang HT, et al. Clinical outcomes of solitary atrial flutter patients using anticoagulation therapy: a national cohort study. Europace. 2019;21:313-321. 